\title{
A Study of the Inter-Cultural Sensitivity among the Faculty of English Language Centre of Jazan University, Saudi Arabia
}

\author{
Saeed Ahmad (Corresponding author) \\ English Language Center, Jazan University, Saudi Arabia \\ E-mail: Saeed_edu@hotmail.com \\ Muhammad Riaz Khan \\ English Language Center, Jazan University, Saudi Arabia \\ E-mail: Riaz_khan655@yahoo.com
}

Received: 22-08-2016

Published: 10-12-2016
Accepted: 27-10-2016

doi:10.7575/aiac.ijalel.v.5n.7p.226
Advance Access Published: November 2016

URL: http://dx.doi.org/10.7575/aiac.ijalel.v.5n.7p.226

\begin{abstract}
The study explored intercultural sensitivity of 103 faculty members of the English Language Centre (ELC) of Jazan University, Saudi Arabia. A quantitative and non-experimental design was adopted for this study in which intercultural sensitivity of the English language teachers was evaluated on five demographic variables (e.g. gender, education, religion, total teaching experience, and experience of teaching in intercultural context). The results revealed that the international faculty of ELC abreast the basic canons of Intercultural adjustments. This suggests that the teachers are not only familiar with different cultural patterns (like beliefs, values and communication styles) they are willing to minimize these differences and adopt universal set of values for effective educational practices. The results indicate the participants' higher level of empathy, respect for others' culture, tolerance on differences and high willingness to integrate with other cultures. The data reveals no statistically significant difference between the two groups in three variables, i.e. gender (Male \& Female), qualification (Masters' \& Ph.D) and religion (Muslims \& Non-Muslims). However, there was found a statistically significant difference in the two groups (Less than ten years \& More than ten years) in two variables, i.e. total teaching experience and teaching experience in intercultural context.
\end{abstract}

Keywords: Adaptability, English Teaching, Intercultural Sensitivity

\section{Introduction}

Today, the process of globalization in education is shaping the world societies in which Intercultural Communicative Competence (ICC) is of the significant importance. Large scale mobility of teachers across borders is a growing demand by the stake holders that is indeed contributing to major reforms in this sector. The establishment of effective intercultural relationship is a well-recognized concept in a global context. The manner how the individuals construe being in different cultures and how ready they are for the intercultural adaptation has remained a matter of great interest for many scholars and researchers. The underlying assumption is that 'as one's experience of cultural difference becomes more complex and sophisticated, one's potential competence in intercultural relations increases' (Hammer et al, 2003). According to this assumption, 'experience does not occur simply by being in the vicinity of events when they occur. Rather, experience is a function of how one construes the events' (Kelly, 1963). Hammer et al, (2003-Pp. 423) explained it as follows:

Individuals who have received largely mono-cultural socialization normally have access only to their own cultural worldview, so they are unable to construe (and thus are unable to experience) the difference between their own perception and that of people who are culturally different. The crux of the development of intercultural sensitivity is attaining the ability to construe (and thus to experience) cultural difference in more complex ways.

The educators play an important role in promoting intercultural dimensions in the students' personality. The goal is to achieve a comprehensive global understanding with respect for diversity and to attain intercultural perspectives for a life-long learning. The researchers and scholars have emphasized the need for developing cross-cultural adjustment in a diversified globalized world for the teachers. Diller \& Moule (2005) claim that many educational institutions profess commitment to support intercultural competence and diversification in their educational set-up, but that is hardly seen in real practice. Students and teachers from diverse cultures experience discrimination in many countries. George \& Louise-Spindler (1994) asserted that the international teachers bring with them personal cultural backgrounds which reflect in their beliefs and assumptions. 


\section{Background of the study}

This study shows partial results of a larger study, a part of which can be seen in Ahmad \& Ahmad (2015) which was taken with the objective to explore the extent of teachers' readiness for the cross-cultural communications within themselves and the students. It was limited to the faculty of English Language Center of Jazan University, Saudi Arabia. Jazan University is one of the leading universities in the region with the aim to academic leadership and excellence in scientific research and innovation in community development and service. The English Language Center of Jazan University was established in 2008 with the purpose to offer general English language and ESP courses to its various departments and faculties. This center is striving hard to provide high quality English pedagogy for its students with staff and faculty members from around the world, like Europe and Western countries, Asia and Africa. The total number of faculty members of ELC is above 400, from which 103 teachers, male and female who belonged to different regions of the world, and from various campuses of the university, participated in this research.

\subsection{The significance and historical development of ICC as a discipline}

Institutes of higher learning across the world are facing a big challenge in producing inter-culturally competent intellectuals. These institutions are concerned with: how many of the international students study at their campus, how many of the foreign faculty members teach their courses and how many of their taught courses abreast the standards of internationalized curriculum. And more so, how many of their students succeed in obtaining admissions in the international institutions abroad. Graduating cross-cultural savvy students is thus an obvious target for many of the colleges and universities across the globe. However, a few institutes address the challenges of making their students adaptable in a new culture.

ICC is now a well-established universal phenomenon. Its history dates back to hundreds of years ago when people from different parts of the world started business and trade with each other and established a new era of internationalization which led to the present situation of globalization. The first work towards ICC is believed to be a book 'The Silent Language' by Hall (1959). This book played an influential role in creating interest in the study of ICC and setting an agenda for new explorations in this context, though some researchers also claim that Hall was not the only scholar working in this direction, his work massively rested on the work of a series of anthropologists and scholars who understood the importance of ICC and played their role in establishing and maintaining international relations between America and the rest of the world. However, it is said that ICC as a separate discipline in college and university education started in 1970s. The historical development of intercultural education as a separate discipline can be traced in America (Polat, 2011) where the presence of a major racial diversity compelled the stakeholders start nationwide discussions on the emerging needs of multicultural, multiethnic and multiracial curriculum. A multicultural education was felt necessary to reduce marginalization of minorities residing in the USA. Since then, an overarching awareness of such issues paved way for the mass-education promoting intercultural elements of education and bringing forth the need of a standardized curricula which may effectively teach students not only to recognize their own cultural diversity but also identifying and respecting cultural identities of the other nations.

In the USA, the concept of multicultural education emerged from the Civil Rights Movement in 1960 (Stuhr, 1994) which led to reconstruction of school and society. It was considered to be a solution of social problems of multiethnic and diversified students who were suffering on the social front due to the ethnocentric views of the prevailing educational system. The emergence of a multicultural education safeguarded civil rights, 'promoting cultural pride and equal learning opportunities for all children in U.S. schools' (Adejumo, 2002, Pp. 34- as quoted in Weiner, 2010), teaching them a curriculum with the features of a cross-cultural curriculum (Gay 2000, Pp. 29- as mentioned in Celik, 2013).

\section{Literature Review}

A plethora of research in exploring the intercultural competence suggests the significance of this topic, yet very few studies have been taken to evaluate the level of adjustability among teachers in the international settings, especially keeping in view the recent increasing cultural diversity and the consequent need to increase intercultural competence among all the stake holders. Chen \& Starosta (2005- Pp. 4) suggested that, 'the development of a global mind-set is pivotal for further human progress'. Many researchers have focused on intercultural competence in education and a number of terms have been coined over time which are used synonymously in the current literature, e.g. Culturally Responsive Teaching (Gay, 2000; Klump \& McNeir, 2005; Villegas \& Lucas, 2002), Culturally Proficient Instruction (Robins et al, 2006), and Culturally Relevant Teaching (Ladson-Billings, 2001) — as mentioned in Bayles (2009). The researchers (like Jodry, 2001; Kellecher, 2006; Ladson-Billings, 1994; Lundgren, 2007) have asserted that culturally responsive teaching affects students' achievement (Bayles, 2009).

\subsection{Assessment of Intercultural Sensitivity:}

Measuring Intercultural Competence and Intercultural Sensitivity among the students and employees have gained popularity in the recent years. In the Intercultural settings, employers increasingly show their concern for the assessment of their employees' level of Intercultural adaptability, and the educational organizations who consider intercultural adjustment as an important outcome of the education they provide to their graduates. An important question at this point arises as to how to accurately and appropriately measure Intercultural adaptability and sensitivity. Lucky enough, various measurement tools have been developed over time by many scholars and experts in this field which are being used by the institutions and organizations worldwide. Fantini (2006b) has mentioned eighty seven 
assessment tools which have been developed and used in numerous contexts worldwide. Research studies in diversified areas, as International Management (for example Adler, 1991; Black, 1990; Black, Gregersen et al, 1992; Black \& Mendenhall, 1990), Overseas Effectiveness (for example Brislin, 1981; Cleveland et al, 1960; Kealey \& Ruben, 1983; Landis \& Brislin, 1983; Landis \& Bhaget, 1996), International Study Abroad (for example Klineberg \& Hull, 1979), International Transfer of Technology and Information (for example Hawes \& Kealey, 1979, 1981; Kealey, 1996), etc., have signified the concept of ICC. Using these assessment instruments allows the employers and educators to assess the effectiveness of their plans, and helps them intervene at the proper times and provide remedial measures to obtain the desired objectives. These assessment tools can be approached easily which are available on commercial or noncommercial basis. Five of these instruments (Lombardi, 2010) which are more frequently used than others, are: the Assessment of Intercultural Competence (Fantini, 2006a), the Intercultural Development Inventory (Hammer et al, 2003), The Intercultural Sensitivity Inventory (Bhawuk \& Brislin, 1992), The Cross-Cultural Adaptability Inventory (Kelly \& Meyers, 1995) and The Cross-Cultural World Mindedness Scale (Piage, 2004). The Intercultural Development Inventory and the Cross-Cultural Assessment Inventory are available on cost while the other three instruments are the emerging non-commercial instruments (Lombardi, 2010). However, more research is needed to validate the constructs of these measurement instruments since the dimensions of intercultural communications are ever evolving and the human behaviors are never stagnant.

Chen \& Starosta (1996) model of measuring the ICC has also been considered important by the experts which comprises three dimensional aspects including INTERCULTURAL AWARENESS, INTERCULTURAL SENSITIVITY, and INTERCULTURAL ADROITNESS. Further, Chen \& Starosta (2000) also prepared an instrument with 5 factors and 24 items to measure the intercultural sensitivity, about which Fritz, et al (2002) claim that - 'the instrument as a whole is a valid one through which a culture-free scale for measuring intercultural sensitivity can be developed'. This model is worthwhile since it integrates cross-cultural attitudes and behavioral skills of the individuals. The originators of this scale employed it during their research with the German students' population of 400 by means of factor confirmatory factor analysis.

\section{Research Methodology}

To achieve the research objectives of this study, a survey study method was selected. A semi structured questionnaire with five demographic variables, i.e. gender, qualification, religion, total teaching experience, and experience of teaching in intercultural settings, along with an Intercultural Sensitivity Scale adopted from Fritz, et al (2002) was delivered to all the campuses of ELC at the Jazan University, Saudi Arabia. This instrument was used because of its easy access, validity issues and appropriateness for the assessment of intercultural communication among the culturally diverse employees. The data was collected and thereon analyzed using quantitative techniques.

\section{Results}

\subsection{Demographics}

A total of 103 faculty members of English Language Centre of Jazan University participated in this study from which forty two (41\%) were male and sixty one $(59 \%)$ were female members. The majority of respondents in this study held a Master's degree (87) which constitutes eighty five percent of the total population. And, there were sixteen Ph.D degree holders who constitute fifteen percent of the population. The participants of this study belonged to different religions, i.e. Muslims constituted the majority (89\%), with other religions like Hindus and Christians (11\%). The sample population has had myriad experiences that were categorized into two, less than 10 years (40\%) and more than 10 years $(60 \%)$. The intercultural experience of the respondents was also categorized into two, less than 10 years $(70 \%)$ and more than 10 years $(30 \%)$.

\subsection{Intercultural Sensitivity}

Bayles (2009) examined seven variables in her study including gender, age, education, bicultural living experience, total years of teaching experience, experience of teaching ethnically diverse students, and years teaching in the bilingual classrooms in her study to assess the intercultural sensitivity of the elementary teachers in bilingual schools. The factors, like gender, age and education have also been examined by Frethiem, 2007; Westrick \& Yuen, 2007; and Helmer, 2007. Following the latter studies, the present study, however, added two variables that were considered to be important, i.e. total teaching experience and the participants' experience of working in the intercultural environment. The present study found no statistically significant difference among the respondents in terms of the above mentioned variables while the statistical level of difference was less than 0.05 on alpha. The results were calculated by assigning $5,4,3,2$ and 1 with every individual positive item in the Intercultural Sensitivity Scale (and the order of assigned marks was in the reverse order with the items with negative statements). The marks obtained by the respondents on every single item were calculated and Mean scores with Standard Deviation were assessed to find any possibly significant difference/s among the population on multiple variables. The overall results, however, showed no statistically significant difference among the double-grouped population on three demographic variables, i.e. gender, age, and qualification. However, a statistically significant difference was found in two demographic variables, i.e. total teaching experience, and the experience of working in the intercultural context (Table 1). 


\begin{tabular}{|c|c|c|c|c|c|c|c|c|}
\hline \multirow[t]{2}{*}{ Groups } & \multirow[t]{2}{*}{$\mathrm{N}$} & \multirow[t]{2}{*}{ Mean } & \multirow[t]{2}{*}{ SD } & \multirow[t]{2}{*}{ S.E (M) } & \multirow[t]{2}{*}{$\mathrm{T}$} & \multirow[t]{2}{*}{ Sig. } & \multicolumn{2}{|c|}{$95 \%$ Confidence interval of Dif } \\
\hline & & & & & & & Lower & Upper \\
\hline \multicolumn{9}{|l|}{ Gender } \\
\hline Male & 42 & 4.528 & 0.505 & 0.078 & -.170 & 0.754 & -.217 & 0.183 \\
\hline Female & 61 & 4.541 & 0.502 & 0.064 & -.169 & & -.218 & 0.184 \\
\hline \multicolumn{9}{|l|}{ Qualification } \\
\hline Masters & 87 & 3.524 & 0.804 & 0.124 & -.108 & 0.953 & -.3320 & 298 \\
\hline Doctorate & 16 & 3.541 & 0.787 & 0.101 & -.107 & & -.335 & 0.300 \\
\hline \multicolumn{9}{|l|}{ Religion } \\
\hline Muslims & 89 & 4.143 & 0.843 & 0.130 & 1.419 & 0.957 & -.096 & 0.578 \\
\hline Others & 14 & 3.910 & 0.850 & 0.109 & 1.422 & & -.096 & 0.578 \\
\hline \multicolumn{9}{|l|}{ Total Exp. } \\
\hline Less than 10 Yrs. & 40 & 3.610 & 0.936 & 0.120 & 4.428 & 0.009 & 0.414 & 1.087 \\
\hline More than 10 Yrs. & 63 & 4.357 & 0.692 & 0.107 & 4.676 & & 0.432 & 1.069 \\
\hline \multicolumn{9}{|l|}{ Intercultural Exp. } \\
\hline Less than 10 Yrs. & 72 & 4.119 & 0.803 & 0.124 & -3.281 & 0.002 & -.677 & -.167 \\
\hline More than 10 Yrs. & 31 & 4.541 & 0.502 & 0.064 & -.3 .024 & & -.701 & -.143 \\
\hline
\end{tabular}

The researchers examined five demographic variables using One-Sample $t$ Test of SPSS 17 making two groups on each, i.e. Gender (Male and Female), Qualification (Masters' and Doctorate), Religion (Muslim and others), Total Experience (Less than 10 years and More than 10 years), and Intercultural Experience (Less than 10 years and More than 10 years). These are the most plausible variables that may affect intercultural sensitivity. The table 1 shows a comparison of results between two groups in every individual variable: in gender, i.e. male and female; in qualification, i.e. masters' and doctorate; in religion, i.e. Muslims and others; in total experience, i.e. less than 10 years and more than 10 years, and in intercultural experience, i.e. less than 10 years and more than 10 years. The data reveals no statistically significant difference in three variables, i.e. gender, qualification and religion. However, in two variables, i.e. total experience and intercultural experience, there was found a statistically significant difference. The significance value was less than .05 on alpha. The Mean score on the two groups in gender was 4.528 and 4.541, SD 0.505 and 0.512 and the $t$ score -.170 and -.170 for male and female respectively with a significance of 0.754 which was higher than the point of significance on 0.05 alpha. Hence, no statistically significant difference was found on this variable. The Mean score on the two groups in qualification was 3.524 and 3.541, SD 0.804 and 0.787 and the $t$ score -.108 and -.107 for masters and doctorate respectively with a significance of 0.953 which was higher than 0.05 alpha. Hence, no statistically significant difference was found on this variable. The Mean score on the two groups in religion was 4.143 and 3.910, SD 0.843 and 0.851 and the $t$ score 1.419 and 1.422 for the two groups Muslims and others with a significance of 0.957 which was higher than the point of significance 0.05 alpha. Hence, no statistically significant difference was found on this variable. The Mean score on the two groups in total experience was 3.610 and 4.357, SD 0.936 and 0.692 and the $t$ score 4.428 and 4.676 in two groups less than 10 years and more than 10 years respectively with a significance of 0.009 which was lesser than the point of significance 0.05 alpha. Hence, statistically significant difference was found on this variable that means the respondents with longer experience in job were more prone to adjustment in the intercultural settings. The Mean score on the two groups in intercultural experience was 4.119 and 4.119, SD 0.803 and 0.502 and the $t$ score -3.128 and -3.024 with a significance of 0.002 which was lesser than the point of significance 0.05 alpha. Hence, a statistically significant difference was found on this variable that means the teachers with longer experience in teaching interculturally diverse classrooms are nearer to the adaptation process as compared to their counterparts with lesser experience.

\section{Conclusion}

The study was taken to evaluate the level of intercultural sensitivity on five variables, i.e. gender, qualification, religion, total experience and the intercultural experience among the faculty of English Language Centre of Jazan University, Saudi Arabia. The participants' responses on the given items in a questionnaire were collected. The results show that the participants belonged to both genders, male and female. They hailed from various religious backgrounds. They have had myriad sources of professional and personal experiences ranging from less than ten to over ten years. They have had myriad experiences of working in the intercultural settings that range from less than ten to over ten years. Their responses on the intercultural sensitivity scale (appendix 1) clearly indicate their readiness and adjustability in the crosscultural settings. They respect cultural differences as indicated on items number 2, 7, 8, 16, 18 and 20. They are confident for intercultural communications as indicated on items number 3, 4, 5, 6 and 10 . They believe in interactional engagement as indicated in items number 1,11,13,21, 22, 23 and 24. They enjoy intercultural interactions as indicated 
in items number 9, 12 and 15. They also show interactive attentiveness with multicultural colleagues as indicated in items number 14, 17 and 19.

\section{Discussion}

'As human society moves to a global community, the demand of cultural interdependency in the macro level and intercultural communication competency in the individual level become stronger' (Fritz et al, 2002). Today, living in a culturally diverse globalized society has become a norm of life for the people rather than an exception. In this sense, a rigorous research is needed to further elaborate complexities involved in fully understanding the implications of intercultural interactions in order to help humanity for a comparatively better adjustment to the ever changing demands of the new world, and to live a peaceful and progressive life. The globalization trends in the modern world have significantly increased the importance of ICC. The internationalization led the stake holders to know how to act successfully in the culturally diversified settings.

Although this study attempted to evaluate the level of intercultural sensitivity and adjustability of the international and multicultural faculty, yet many other measurement instruments and scales could be used for a clearer picture of the phenomenon. The scarcity of resources hampered to access some possibly more authentic and reliable tools available at cost for this current study. Further research can be taken with a larger population, using more sophisticated and authentic techniques as mentioned above. The research should also be taken with a population from different disciplines at college and university levels. A comparative analysis of the phenomenon will also be a subject of interest for many researchers.

\section{Acknowledgement}

The researchers would like to acknowledge the contribution of the entire population of this study. Their sincere thankyou is also due to the administration of English Language Centre (Jazan University, Saudi Arabia) for their unceasing support and facilitating the process of data collection.

\section{References}

Adejumo, C. O. (2003). Considering multicultural art education. Art Education, 55(2), 33-39.

Adler, N. (1991). International dimensions of organizational behavior (2 ${ }^{\text {nd }}$ Ed.). Boston: PWS-Kent.

Ahmad, S. \& Ahmad, N. (2015). Fostering Inter-Cultural Communication Skills among Learners through Teaching English as an International Language. International Journal of Applied Linguistics and English Literature, 4(6), 52-57.

Bayles, P.P. (2009). Assessing the Intercultural Sensitivity of Elementary Teachersin Bilingual Schools in a Texas School District. Doctorate dissertation, retrieved on 22.06.2015

athttps://conservancy.umn.edu/bitstream/.../Bayles_umn_0130E_10245.pdf.

Bhawuk, D.P.S., \& Brislin, R.W. (1992). The measurement of intercultural sensitivity using the concepts of individualism and collectivism. The International Journal of Intercultural Relations, 16(4), 413-436.

Black, J. S. (1990). The relationship of personal characteristics with the adjustment of Japanese expatriate managers. Management International Review, 30, 119-134.

Black, J. S., \& Mendenhall, M. (1990). Cross-cultural training effectiveness: A review and theoretical framework for future research. Academy of Management Review, 15, 113-136.

Black, J. S., Gregersen, H. B., \& Mendenhall, M. E. (1992). Global assignments. San Francisco, CA: Jossey-Bass.

Brislin, R. W. (1981). Cross-cultural encounters: Face-to-face interaction. Elmsford, NY: Pergamon.

Byram, M; Nocholas, A \& Stevens, D. (2001). Developing Intercultural Competence in Practice. Clevedon: Multilingual Matters

Celik, S. (2013) Cultural Perspectives of Turkish ELT Coursebooks: Do StandardizedTeaching Texts Incorporate Intercultural Features? Education and Science, 38(167).

Chen, G.M. \& Starosta, W.J. (1996).Intercultural communication competence: a synthesis. Communication Yearbook, 19, 353-383.

Chen, G.M. \& Starosta, W.J. (1998). A review of the concept of intercultural sensitivity. Human Communication, 1, 116.

Chen, G.M. \& Starosta, W.J. (2000). The development and validation of the intercultural communication sensitivity scale. Human Communication, 3, 1-15.

Chen, G. M., \& Starosta, W.J. (2005). Foundations of intercultural communication.Lanham, MD: University Press of America.

Cleveland, H., Mangone, G., \& Adams, J. (1960). The overseas Americans. New York: McGraw-Hill. DeVellis, R. F. (1991). Scale development. ThousandOaks, CA: Sage.

Diller, J.V., \& Moule, J. (2005). Cultural competence: A primer for educators. Belmont, CA: Thomson Wadsworth. Fantini, A.E. (2006a) Exploring and Assessing Intercultural Competence. Retrieved June 13, 2010, from http://www.sit.edu/SITOccasionalPapers/feil_research_report.pdf.

Fantini, A.E. (2006b). Assessment tools of Intercultural Communicative Competence. Retrieved on 12.12.2015 from: federationeil.org/documents/AppendixF.pdf.

Fretheim, A.M. (2007). Assessing the intercultural sensitivity of educators in an American international school. (Doctoral dissertation, University of Minnesota). Dissertation Abstracts International, 68 (12). (UMI No. 3292934). 
Fritz, W., Mollenberg, A., \& Chen, G.M. (2002). Measuring Intercultural Sensitivity in Different Cultural Contexts. Intercultural Communication Studies, 11 (2), 165-176.

Gay, G. (2000). Culturally responsive teaching: Theory, research, \& practice. NewYork, NY: Teachers College Press.

George, S., \& Louise-Spindler (1994). Pathways to Cultural Awareness: Cultural Therapy with Teachers and Students, Thousand Oaks, CA: Corwin Press.

Hall, E.T. (1959). The Silent Language, Doubleday \& Company, Inc., Garden City, New York: USA

Hammer, M. (2012). The Intercultural Development Inventory: A new frontier in assessment and development of intercultural competence. In M. Vande Berg, R.M. Paige, \& K.H. Lou (Eds.), Student Learning Abroad (Ch. 5, pp. 115136). Sterling, VA: Stylus Publishing.

Hammer, M.R., Bennett, M.J., \& Wiseman, R. (2003). Measuring Intercultural Sensitivity: The intercultural development inventory. International Journal of Intercultural Relations, 27, 421-443.

Hawes, F., \& Kealey, D. J. (1981). An empirical study of Canadian technical assistance. International Journal of Intercultural Relations, 5(3), 239-258.

Hawes, F., \& Kealey, D. J. (1979). Canadians in development: An empirical study of adaptation and effectiveness on overseas assignment. Ottawa, Ontario. Communication Branch Briefing Center, Canadian International Development Agency.

Helmer, J. (2007). Factors influencing the referral of English language learners within an international elementary school: A mixed methods approach. (Doctoral dissertation, University of Minnesota). Dissertation Abstracts International, 68 (05). (UMI No. 3263073).

Jodry, E.O. (2001). Hispanic academic advancement theory: An ethnographic study of students participating in an urban Texas high school advanced diploma program. (Doctoral dissertation, Sam Houston State University). Dissertation AbstractsInternational, 63 (07), 2436A (UMI No. 3059691).

Kealey, D. J. (1996). The challenge of international personnel selection. In D. Landis, \& R. S. Bhagat (Eds.), Handbook of intercultural training ( $2^{\text {nd }}$ Ed.) (pp. 81-105). Thousand Oaks, CA: Sage.

Kealey, D. J., \& Ruben, B. D. (1983). Cross-cultural personnel selection criteria, issues, and methods. In D. Landis, \& R.W. Brislin (Eds.), Handbook of intercultural training, Vol. 1: Issues in theory and design (pp. 155-175). New York: Pergamon.

Kelleher, W.C. (2006). A twenty-year history of Rainbow sections of first-year composition. (Doctoral dissertation, Arizona State University). DissertationAbstracts International, 67 (06), (UMI No. 3220312).

Kelly, G. (1963). A theory of personality: The psychology of personal constructs. New York: Norton.

Kelley \& Meyers (1995). The cross-cultural adaptability inventory: Self-assessment. Minneapolis: MN: NCS Pearson.

Klineberg, O., \& Hull, F. (1979). At a foreign university. New York: Praeger.

Klump, J., \& McNeir, G. (2005). Culturally responsive practices for student success: A regional sampler. Northwest Regional Educational Laboratory. RetrievedJanuary 31, 2015, at http://www.nwrel.org/request/2005june/textonly.html. Ladson-Billings, G. (1994). The dream-keepers: Successful teachers of African American children. San Francisco: Jossey-Bass.

Ladson-Billings, G. (2001). Crossing over to Canaan: The journey of new teachers in diverse classrooms. San Francisco: Jossey-Bass.

Landis, D., \& Bhagat, R. S. (1996). Handbook of intercultural training (Eds.) (2 ${ }^{\text {nd }}$ Ed.). Thousand Oaks, CA: Sage.

Landis, D., \& Brislin, R. W. (1983). Handbook of intercultural training (Eds.), Vol. I: Issues in theory and design. New York: Pergamon.

Lombardi, R.M. (2010). Assessing Intercultural Competence: A Review, NCSSSMST Journal. Retrieved on 11.05.2015 from http://files.eric.ed.gov/fulltext/EJ930654.pdf

Lundgren, C.A. (2007). Culturally sensitive teaching: Exploring the developmental process. (Doctoral dissertation, University of Minnesota). Dissertation Abstracts International, 68 (03), (UMI No. 3256875).

Paige, M.R. (2004). Instrumentation in Intercultural Training. In Dan Landis, Janet. M. Bennett, \& Milton, J. Bennett (Eds.), Handbook of Intercultural Training ( $3^{\text {rd }}$ Ed., Pp 147-165), Thousand Oaks, CA: Sage.

Polat, S. (2011). The attitudes of school directors to the multicultural education in Turkey. Mediterranean Journal of Social Sciences, 2(2), 385-393.

Robins, K.N., Lindsey, R.B., Lindsey, D.B., \& Terrell, R.D. (2006). Culturally proficient instruction: A guide for people who teach (2nd Ed.). Thousand Oaks,CA: Corwin Press.

Stuhr, P.L. (1994). Multicultural art education and social reconstruction. Studies in Art

Education, 35(3), 171-178.

Villegas, A. M., \& Lucas, T. (2002). Educating culturally responsive teachers: A coherent approach. Albany, NY: State University of New York Press.

Weiner, S.D. (2010). My Experiences of Integrating a Cross-cultural Curriculum with Latino Students in an Art Education Classroom, Thesis M.A. $\quad$ retrieved $\quad$ on 21.04 .2015 http://scholarworks.gsu.edu/cgi/viewcontent.cgi?article=1061\&context=art_design_these.

Westrick, J.M. \& Yuen, C.Y.M. (2007). The intercultural sensitivity of secondary teachers in Hong Kong: A comparative study with implications for professional development. Intercultural education, 18(2), 129-145. 


\begin{tabular}{|c|c|}
\hline & Statements on Intercultural Sensitivity \\
\hline$(1)$ & I enjoy interacting with people from different cultures. \\
\hline$(2)$ & I think people from other cultures are narrow minded. \\
\hline (3) & I am pretty sure of myself in interacting with people from different cultures. \\
\hline (4) & I find it very hard to talk in front of people from different cultures. \\
\hline (5) & I always know what to say when interacting with people from different cultures. \\
\hline (6) & I can be as sociable as I want to be when interacting people from different cultures. \\
\hline (7) & I don't want to be with people from different cultures. \\
\hline (8) & I respect the values of people from different cultures. \\
\hline (9) & I get upset easily when interacting people from different cultures. \\
\hline$(10)$ & I feel confident when interacting with people from different cultures. \\
\hline$(11)$ & I tend to wait before forming an impression of culturally-distinct counterparts. \\
\hline$(12)$ & I often get discouraged when I am with people from different cultures. \\
\hline (13) & I am open minded to people from different cultures. \\
\hline$(14)$ & I am very observant when interacting people from distinct cultures. \\
\hline$(15)$ & I often feel useless when interacting with people from different cultures. \\
\hline$(16)$ & I respect the ways people from different cultures behave. \\
\hline$(17)$ & I try to obtain as much information as I can when interacting people from different cultures. \\
\hline$(18)$ & I would not accept the opinions of people from different cultures. \\
\hline$(19)$ & I am sensitive to my culturally-distinct counterparts' subtle meanings during interaction. \\
\hline$(20)$ & I think my culture is better than other cultures. \\
\hline$(21)$ & I often give positive responses to my culturally distinct counterparts during our interaction. \\
\hline$(22)$ & I avoid those situations where I will have to deal with culturally distinct persons. \\
\hline$(23)$ & $\begin{array}{l}\text { I often show my culturally distinct counterpart my understanding through verbal and non- } \\
\text { verbal cues. }\end{array}$ \\
\hline (24) & $\begin{array}{l}\text { I have a feeling of enjoyment towards differences between my culturally distinct } \\
\text { counterpart and me. }\end{array}$ \\
\hline
\end{tabular}

